УДК 78.2У; 78.491

DOI https://doi.org/10.31723/2524-0447-2021-32-1-34

\author{
Чен Менвей \\ ORCID: 0000-0002-1317-4013 \\ аспірантка кафедри історії музики \\ Львівської національної музичної академії імені М. В. Лисенка \\ 862564258@qq.com
}

\title{
АСПЕКТИ ДІЯЛЬНОСТІ ВИДАТНОГО УКРАЇНСЬКОГО СКРИПАЛЯ ОЛЕКСАНДРА ДЗИГАРА В КИТАЇ В ПЕРШІЙ ПОЛОВИНІ ХХ СТ.
}

\begin{abstract}
3'ясовуючи ступінь участі в Китаї скрипалів з України у першій половині XX cm. - етапі становлення китайського професійного скрипкового мистецтва) - необхідним у дослідженні є аналіз матеріалів періодичних джерел та збережених кониертних афіш зазначеного періоду. В процесі аналізу иих матеріалів удалось виявити значну кількість найбільш активних, яскравих і важливих для розвитку китайського скрипкового мистецтва скрипалів з України, які, як виявилось, від початку XX ст. здійснювали там упродовж майже чотирьох десятків років дуже насичену (або менш активну) кониертну діяльність містами Піднебесної, викладали гру на скрипці в китайських навчальних інституціях різних рівнях, брали участь у музично-суспільній праці. Окрім багатьох інших, виявлено постать Олександра Дзигара - талановитого, але дотепер не зовсім відомого в Україні скрипаля, який зробив значний внесок у справу професіоналізації скрипкового мистецтва Китаю на етапі його становлення. Вивчення постаті $i$ творчої діяльності Дзигара як ключової фігури на етапі становлення китайського скрипкового мистецтва дотепер залишалось поза увагою дослідників і не висвітлювалось у музикознавчих праиях. Отжее, мета роботи полягає в дослідженні аспектів діяльності О. Дзигара та визначенні його ролі в популяризації творів ансамблевої західноєвропейської та української музики в Китаї у першій половині XX $\mathrm{cm}$. Методологія дослідження спирається на поєднання біографічного, музикознавчого та джерелознавчо-пошукового методів, що в сукупності стали важлливии для визначення домінантної риси національної свідомості українського скрипаля. Наукова новизна полягає в значному доповненні біографічних відомостей про О. Дзигара як виконавия $i$ популяризатора в Китаї творів українських композиторів. Висновки. Серед українських музикантів кількісно значної української громади в Харбіні О. Дзигар став найпомітнішою і найвидатнішою фігурою в процесі становлення китайського камерно-інструментального вико-
\end{abstract}


навства і в популяризації в Китаї класичних творів західноєвропейської та української музики.

Ключові слова: Олександр Дзигар, суспільно-громадська діяльність, камерний ансамблевий репертуар, українські композитори.

Chen Mengwei, Postgraduate Student at the Department of Music History of the Lviv National Music Academy named after Mykola Lysenko

Aspects of the activity of the outstanding Ukrainian violin Alexander Dzigar in China in the first half of the XX century

Finding out the degree of participation in China of violinists from Ukraine in the first half of the twentieth century (stage of formation of Chinese professional violin art), necessary for the study was the analysis of materials from periodical sources and preserved concert posters of this period. During the analysis of these materials it was possible to identify a significant number of personalities of the most active, bright and important for the development of Chinese violin art violinists from Ukraine, who, as it turned out, from the beginning of the twenties century for almost four decades they performed very intense (or less active) concert activities in the cities of the Celestial Empire, taught violin in Chinese educational institutions of various levels, and participated in musical and social work. Among many others, the figure of Oleksandr Dzygar was discovered - a talented but still almost unknown violinist in Ukraine, who made a significant contribution to the professionalization of Chinese violin art at the stage of its formation. The study of the figure and creative activity of Dzygar as a key figure at the stage of formation of Chinese violin art has so far remained out of the attention of researchers and has not been covered in musicological works. So, the purpose of the work is to study aspects of $O$. Dzygar's activity and determine his role in the popularization of Ukrainian music works in China in the first half of the twentieth century. The research methodology is based on the combination of biographical, musicological and source-researching methods, which together became important for determining the dominant feature of the national consciousness of the Ukrainian violinist. The scientific novelty appears in a significant addition to the biographical information of $O$. Dzygar as a performer and popularizer of works by Ukrainian composers in China. Conclusions. Among the Ukrainian musicians of the very large Ukrainian community in Harbin, O. Dzygar became the most prominent and outstanding figure in the process of formation of Chinese chamber and instrumental performance and in the popularization of works of Ukrainian music in China.

Key words: Oleksandr Dzyhar, public activity, chamber ensemble repertoire, Ukrainian composers.

Актуальність теми дослідження. Діяльність Олександра Дзигара - видатного українського музиканта, який до 1945 р. працював у Китаї, - тривалий час залишалась поза увагою дослідників. У першій половині XX ст. на Півночі Китаю він був одним із найактивніших суспільних і музичних дія- 
чів української колонії, що натхненно і різнобічно сприяли піднесенню національної свідомості українців. Після вимушеного повернення на Батьківщину (в серпні 1945 р., коли представники радянського військового комісаріату його допитали і таємно вивезли до СРСР) «йому сфабрикували справу 3 «українського буржуазного націоналізму» ${ }^{1}$. Дзигара було звинувачено в антирадянській діяльності, у членстві в українських організаціях, засуджено і відправлено відбувати покарання на Колимі. Там він провів 30 років життя (20 із них провів у таборах, останні 10 років працював у Магадані). Після переїзду до Москви (1975) до кінця життя продовжував там діяльність у суспільному і культурному житті української громади. Організація власної суспільно-громадської та виконавської діяльності Дзигара мала вагоме значення в процесі становлення в Китаї професійного камерно-інструментального виконавства та в популяризації у далекому зарубіжжі творів українських композиторів.

Мета дослідження - дослідити аспекти суспільної діяльності О. Дзигара в українській громаді Харбіна та його виконавський репертуар у Китаї як скрипаля в складі камерних ансамблів.

Наукова новизна. Постать українського музиканта Олександра Дзигара в українських історичних джерелах відома 3 позицій активного суспільного діяча на Півночі Китаю і як блискучого виконавця, що одним із перших почав популяризувати в Китаї класичні твори західної ансамблевої музики. У статті вперше досліджено виконавський репертуар О. Дзигара і доповнено біографічні відомості про нього як активного популяризатора в Китаї творів української музики.

Виклад основного матеріалу. Олександр Артамонович Дзигар (1916, Харбін - 2011, Москва) - маловідомий в Україні скрипаль-віртуоз, один із найвизначніших діячів української музичної діаспори в Китаї першої половини XX ст.

Батько О. Дзигара (родом з села Білашки Погребіщенської волості (Вінницька обл.)) відбував під час російсько-япон-

\footnotetext{
1 В. Ідзьо зазначав, що саме так уперше про це написав колишній в'язень Михайло Ільвес: «За антирадянську діяльність і за активну діяльність у СУМ та в УДС з 1933 до 1946 рр., в 1946 р. Олександру Артамоновичу Дзигару сфабрикували справу з «українського буржуазного націоналізму», його було заарештовано і відправлено на Магадан» [5, с. 6].
} 
ської війни службу в Порт-Артурі, після чого залишився в Харбіні, де працював у торговому домі Чурина [5, с. 4]. Тут 1916 р. народився його син - майбутній видатний скрипаль i український громадський діяч Олександр Дзигар.

Увага до вивчення постаті і творчості цього непересічного українського діяча розпочалась лише на початку 2000-х рр. Саме в цей час з'явились поодинокі статті, в яких висвітлювалися окремі факти з його життя та діяльності. Першою серед таких у газеті «Самостійна Україна» 2000 р. з'явилась стаття історика В. Чорномаза «Доля харбінського українця» [12], в якій автор уперше опублікував інформацію про походження Дзигара і про його членство в українських організаціях Українська Далекосхідна Січ і Союз Української Молоді в Харбіні в першій половини XX ст. Цього ж року опубліковано коротенький спогад товариша Дзигара у засланні Михайла Ільвеса «Прощальне адажіо для скрипки з розлукою» [6].

У 2004 р. історик А. Попок, працюючи над включенням до десятитомного видання «Енциклопедія історії України» статей про важливих для української історії та культури постатей, що діяли в умовах далекосхідної еміграції, розмістив статтю «Дзигар Олександр». У ній уперше, крім фіксації найважливіших сторінок його суспільно-громадської роботи в Китаї, арешту і ув'язнення, вчений подав стислу інформацію про музичну освіту Дзигара (у Вищій музичній школі імені О. Глазунова, яку закінчив 1936 р. в класі професора скрипки У. Гольдштейна і камерного ансамблю у В. Трахтенберга), про працю після закінчення школи солістом камерного ансамблю «Ямато-готель» у місті Мукден (сьогодні Шеньян) і про продовження музичної діяльності на засланні (був солістом, концертмейстером, диригентом і художнім керівником Магаданського музично-драматичного театру).

2010 р. у збірці наукових статей Університету «Львівський Ставропігіон» український громадський діяч і соратник О. Дзигара в Харбіні Віктор Ідзьо розширив матеріали про суспільну працю свого товариша в Китаї, про його арешт і відновлення після 1975 р. громадської праці в Москві [5, c. 4-10].

У 2014 р. вперше з'явилось дослідження китайського музиканта Сун Жуй Луна (тепер декана Сючанського університету), в якому вперше дешо розширено інформацію про виконавську діяльність Дзигара. Сун Жуй Лун конкретизував 
географію концертно-гастрольних виступів Дзигара в Китаї (в містах Харбін, Шанхай, Шеньян) та в Японії (Нанао, Санья, Йокогама) і додав, що відразу після закінчення харбінської Вищої музичної школи В. Трахтенберг періодично включав Дзигара (як кращого іiі випускника) до складу власного квартету «Кантилена». 3 цим квартетом Дзигар розпочав свою концертно-виконавську кар'єру. В складі цього ансамблю йому навіть пощастило зробити низку записів на грамплатівки. У 1934 р. Трахтенберг запросив Дзигара до постійного складу струнного квартету при симфонічному оркестрі Китайської Східної залізниці як другого скрипаля, а в 1943-1945 pр. він працював солістом Харбінського симфонічного оркестру [10, с. 98].

У Дзигара, народженого в далекій еміграції, вихованого батьками і українським середовищем, від юних років міцно сформувалось глибоке усвідомлення своєї національної ідентичності. Він, наділений рисами лідера і невтомного борця за відстоювання інтересів українців, став активним учасником культурного життя української громади. У 1933 р. Дзигар вступив до Союзу Української Молоді. В. Ідзьо писав: «СУМ $<\ldots>$ був національною організацією української молоді, він ставив за мету об'єднати всі українські молоді сили, розсіяні на Далекому Сході» [5, с. 5]. Дзигар, намагаючись зміцнювати серед української молоді Харбіна почуття своєї національної ідентичності, сприяв реалізації культурних запитів української громади і всіляко популяризував у колах молоді українську музичну культуру.

Музикант брав найактивнішу участь в усіх мистецьких проектах, що відбувалися в культурному середовищі міста, організовував і сам був учасником концертів класичної музики, долучався до постановок в Українському клубі улюблених українцями оперних («Запорожець за Дунаєм» С. Гулака-Артемовського, «Майська ніч» М. Лисенка) і драматичних («Наталка Полтавка» Котляревського, Циганка Аза» Старицького) вистав із музикою.

Повагу та визнання громадськістю талантів українського скрипаля засвідчує короткий вислів, наведений у журналі «Далекий Схід» за 1938 р., який зберігся в документах російського скрипаля Г. Сидорова. Сидоров, як і Дзигар, народився в Харбіні і в певних роках був разом із ним учасником струнного квартету. В статті журналу «Успіхи молодого 
скрипаля» (автора не зазначено) Дзигара називали «серцем мистецького життя українців» [11, с. 9]. Також у цій статті повідомлялось, що вже у двадцятилітньому віці (від 1936 р.) його обрано головою молодіжної націоналістичної організації Українська Далекосхідна Січ [11, с. 9]. Молодому скрипалеві дуже імпонували напрями діяльності цієї організації, бо, окрім іншого, Січ багато уваги приділяла організації культурного життя українців - проведенню своїх вечорів, лекцій, концертів, постановкам вистав, а цей різновид діяльності привертав його увагу. Розвиваючи суспільно-громадську і музично-публіцистичну сфери своєї діяльності, Дзигар наприкінці 1930-х рр. працював також видавцем журналу української громади «Молодий українець», у якому, крім іншого, здійснював огляди культурного і мистецького життя українців.

Збираючи інформацію (з різних архівних джерел та з коротеньких, немов «між іншого», згадок у спогадах сучасників), удалось істотніше заповнити прогалини в його творчій біографіï.

Роки навчання у Вищій музичній школі імені О. Глазунова стали особливо щасливим періодом його життя, оскільки в цей час він мав унікальну можливість знайти своє покликання в ансамблевому виконавстві та отримати поштовх до активної діяльності у цій сфері, що стала головною площиною його самореалізації як музиканта.

Педагог Дзигара Уріель Гольдштейн був випускником Берлінської Королівської академії музики за класом скрипки у видатного французького віртуоза Анрі Марто [2]. В роботі зі своїми учнями він розкривав отримані від Марто найтонші таємниці досягнення вищої виконавської майстерності, вироблення індивідуального підходу до трактування музичного твору в процесі його виконання, можливостей застосування різних варіантів прочитання та інтерпретації музичного тексту. Марто називали палким популяризатором творів сучасної музики і неперевершеним інтерпретатором жанрових п'єс. Ці вміння Гольдштейн прищеплював улюбленому учневі. В майбутньому, коли Дзигар став відомим музикантом, про нього писали, що він є «одним із кращих виконавців Харбіна, <...> саме його скрипці довірили насолоджувати слух лорда Лінтона - голови делегації Ліги націй» [10, с. 98], особливо виокремлюючи його прагнення представляти аудиторії нові твори сучасних композиторів. Про рівень сольного виконав- 
ства Дзигара свідчили його перемоги на конкурсах молодих скрипалів Китаю, що рік за роком відбулися в 1932 і 1933 рр.

Дзигар як виконавець блискуче виявив себе в галузі ансамблевого інструментального музикування. Спочатку це була робота соліста в камерному ансамблі «Ямато-готель» і в квартеті «Кантилена», пізніше - як учасника ансамблів різних складів (у тріо, в дуетах), виступи яких він організовував із різних нагод особисто; працював першим скрипалем у струнному квартеті Харбінського симфонічного товариства. 3 цим колективом, що організовував особливо інтенсивну гастрольну діяльність, було зіграно дуже багато творів західноєвропейських і російських композиторів. Багато подорожуючи містами Китаю і Японії, на гастролі до США Дзигар не поїхав, бо розпочинав у цей час (від 1936 р.) велику працю на посаді головного редактора журналу «Молодий українець» і активізував свою діяльність в українських організаціях СУМ і УДС.

На жаль, обсяг виконавського репертуару Дзигара через знищення (або занесення до спеціальних секретних сховищ) всіх документів про його діяльність у Китаї встановити не вдалось. Проте в процесі кропіткої пошукової праці, аналізуючи матеріали про концертну діяльність російських музикантів Харбінського симфонічного товариства, вдалось заповнити цю прогалину. Керівництво товариством здійснювалось російським урядом, що впливало на репертуар усіх його виконавських сил - оркестрів, камерних ансамблів, солістів. Музиканти з України (як такі, що приїхали в Китай із СРСР) позиціонувались як російські. Виконувались насамперед твори російських композиторів, а також найпопулярніших у Китаї західноєвропейських; з українських пріоритетними залишалися лише твори Р. Глієра і С. Василенка.

Наведемо декілька фрагментів з уперше виявлених у давній періодиці повідомлень про виконавську діяльність Дзигара та фрагментів з опублікованих матеріалів російських митців:

Зі спогадів піаністки В. Бєлоусової про концерт 29 січня 1942 р.: «Особливо запам'ятався концерт у польському клубі «Госпуда Польська», де я грала зі скрипалем О. Дзигаром coнату c-moll Гріга і сонату Рубінштейна, а також тріо Чайковського з тим самим скрипалем і віолончелістом О. Погодіним» [1, с. 152]. Далі Бєлоусова вказувала на діяльність струнного квартету, в якому Дзигар грав партію першої скрипки: 
«Учасниками цього квартету влаштовувалось найбільше циклів квартетної музики. Їхні концерти проводились у концертному залі Комерційного зібрання й у Білому залі готелю «Модерн». Вони добре відвідувалися любителями музики» [1, с. 147-148].

У дописах у газеті «Рубіж» у грудні 1943 р. розміщено ще одну інформацію від цієї піаністки: «Слід указати на ювілейний цикл, проведений камерним ансамблем Харбінського симфонічного товариства. Виконували усі три Струнні квартети і Серенаду для струнного оркестру ор. 48 Чайковського. Для квартету іiі переробив Дзигар. <..> Успішний продаж попередніх квитків забезпечив аншлаг, який постійно буває на виступах цього квартету» [7, с. 12-13].

10 травня 1943 р. в «Рубежі» було розміщено статтю «Пам’яті російського генія» про відзначення в Харбіні творчості Чайковського, в якій повідомлялось: «Музичний сезон 1943 р. пройшов під знаком ювілейного року одного з найвеличніших російських композиторів. <...> Ініціативою Харбінського симфонічного товариства пам'яті великого лірика-мелодиста було влаштовано багато вечорів камерної музики. Особливо відзначимо концерти в готелі «Модерн» ансамблю в складі О. Дзигара, братів Погодіних і Г. Сидорова, які виконували романтичні струнні квартети (Чайковського Ре мажор і Фа мажор, Брамса ля мінор, Мендельсона «Юнацький квартет» і квартет ор. 12). Як завжди, виступи ансамблю викликали у слухачів справжній емоційний сплеск» [7, с. 8].

У грудні цього ж року в статті газети «Десятий камерний концерт Харбінського симфонічного товариства»: «Одне 3 видних місць Харбінського симфонічного товариства займають камерні концерти, які проводить квартет Дзигара. Ці здібні музиканти присвятили себе пропагуванню камерного мистецтва і виховуванню музичного смаку в молоді. <..> Камерний сезон цього року в «Модерні» мав особливий успіх» [3, с. 4]. У переліку виконаних квартетом композицій цього сезону були згадані твори Гріга, Глінки, Генделя, Мендельсона, Аренського, Шуберта і Чайковського; особливо відзначалась «натхненна гра Дзигара в складі інших ансамблів, які виконали Струнний квінтет Шуберта (ор. 163) і Тріо № 1 Мендельсона» [4, с. 5].

У пошуках підтвердження фактів про послідовне ознайомлення Дзигаром своїх співвітчизників із творами українських 
композиторів усе ж було віднайдено декілька унікальних прикладів. Перший із них стосується 1932 р.: сам скрипаль у короткому повідомленні після концерту, опублікованому в журналі української молоді в Харбіні «Далекий Схід» (серпень 1932 р.), повідомляв, що «публіка з цікавістю слухала «Квартет» Лисенка в романтичному стилі і захопилась національною своєрідністю музики» [3, с. 30]. Очевидно, під «національною своєрідністю музики» струнного Квартету (1869) основоположника української класичної музики Дзигар мав на увазі пізнавані українцями фольклорні мелодійні та ритмічні звороти і почуті в ньому цитовані мелодії улюблених українських народних пісень - ліричної пісні-романсу «Ой не світи, місяченьку» і жартівливої «Ой під горою, під перелазом». Українські слухачі, «відчувши в цій музиці дух свого співвітчизника, який завжди обстоював думку про порятунок української народної пісні від забуття, бажали слухати цей твір знову і знову» [3, с. 31].

Також інформація про виконання цього твору Лисенка в Харбіні знайшлась у спогадах російського скрипаля Г. Сидорова, який, зокрема, писав: «...ру Дзигара відрізняли соковитий звук, бездоганна чистота інтонації, великий розвиток лівої руки і різноманітність смичка» [9, с. 142].

Другий факт видається ще більш цікавим і навіть унікальним. У 1936 р. - році завершення навчання Дзигара у Вищій музичній школі імені Глазунова в магазині «Кантилена» відбувся черговий концерт камерної музики. Газета «Рубіж» повідомляла, що в цьому концерті «У виконанні скрипаля Олександра Дзигара і піаніста Віктора Костевича прозвучав твір «Дурнички» невідомого композитора Лопатинського. Гра виконавців була яскравою, темпераментною і до межі емоційною» [8, с. 23]. Очевидно, дописувач мав на увазі твір Ярослава Лопатинського для скрипки і фортепіано «Дрібнички».

Віднайдене коротке евристичне для дослідників оголошення в газеті «Рубіж» сьогодні викликає відразу декілька запитань. По-перше, чи справді це стає першим документально підтвердженим фактом виконання скрипалем у Китаї твору української музики? (На цей час йому було всього 20 років). Яким чином у далекому Китаї став відомим твір українського композитора з Галичини Ярослава Лопатинського (1871-1936) ще за його життя? (Лопатинський помер 12 січня 1936 р. Концерт відбувся в серпні цього ж року). 
Лопатинський був композитором, який навіть не отримав професійної музичної освіти (адже за фахом він був лікарем), проте був високо оцінений ще за життя своїми видатними сучасниками С. Людкевичем і В. Барвінським. Вони вважали, що твори Лопатинського значно наближають його до творчості тих видатних українських композиторів, які закладали фундамент професійної української музичної культури, спрямованої на виховання національної свідомості. По-друге, яким чином у Харбіні могли опинитися ноти цього твору Лопатинського ще за життя самого композитора? Можливо, ноти особливо улюблених творів своїх національних композиторів, зокрема й Лопатинського, привозили туди українські емігранти? За життя Лопатинського його яскраво емоційні солоспіви з надзвичайно красивою і близькою до народних пісень мелодикою швидко ставали дуже популярними. Напевно, саме такі твори хотіли б слухати українці в еміграції, тому й могли завозити їх на чужину. Можемо зробити й припущення, що деякі 3 них могли завозитися до Китаю членами товариства «Січ», що діяло в багатьох країнах поселення українців. Лопатинський у 1893-1898 рр. навчання у Віденському університеті був активним членом музичного гуртка українського студентського товариства «Січ». Дзигар був активним членом товариства «Українська Далекосхідна Січ» в Харбіні й одним зі своїх завдань уважав поширення в українській громаді творів українських композиторів. Це могло сприяти виявленню його особливого інтересу до творчості Лопатинського - свого сучасника, соратника за світоглядом і завданнями «Січовиків». У прагненні поширювати кращі твори української культури серед молоді він міг реалізувати це завдання виконанням «Дрібничок» Лопатинського в Китаї. Зазначимо, що в можливості реалізації таких акцій виявлялася та особлива ситуація Харбіна, що дозволяла українцям поширювати і плідно розвивати свою культуру.

Висновки. Серед українських музикантів кількісно значної української громади Олександр Дзигар став найпомітнішою і найвидатнішою фігурою в процесі становлення в Китаї камерно-інструментального виконавства. Цілковито присвятивши себе виконавській діяльності, він не залишив після себе значної когорти учнів-послідовників як педагог. Проте його діяльність як виконавця-ансамбліста була дуже активною і поряд із представниками інших західних майстрів 
скрипкового мистецтва, що діяли тут у цей період, виявилась особливо важливою в справі розвитку концертного життя та професіоналізації в Китаї скрипкового виконавства. Внесок у цей процес скрипаля Дзигара як непересічного представника українства в далекому Китаї стає ще більш важливим щодо його справді дуже насиченої громадської і музично-суспільної діяльності в середовищі української громади і не лише в справі популяризації в Китаї кращих зразків європейської класичної музики, а й у пропаганді в далекій еміграції творів скрипкового репертуару українських композиторів.

\section{СПИСОК ЛІТЕРАТУРИ}

1. Белоусова В.В. Моя жизнь и музыка. Русский Харбин. Москва: Наука, 2005. С. 145-152.

2. Гольдштейн Уриэль (Юлий) Моисеевич - скрипач. Наш Баку. История Баку и бакинцев. URL: https://www.ourbaku.com/index.php. (Дата зверн. 17.02.2021).

3. Далекий Схід. Журнал української молоді в Харбіні. Харбін, серпень 1938. 32 с.

4. Десятый камерный концерт Харбинского симфонического общества. Закрытие сезона 1943/1944 года. Рубеж. Харбин, 1944, $24 \mathrm{c}$.

5. Ідзьо Віктор. Олександр Дзигар - український громадський діяч в Харбіні та Москві. Івано-Франківськ: Сімик, 2015. С. 4-10.

6. Ильвес М. Прощальное адажио для скрипки с разлукой. Восточный форпост. Магадан, 2000. №1. С. 24-25.

7. Памяти русского гения (K предстоящей постановке оперы “Евгений Онегин»). Рубежс. Харбин, 1943, 10 мая. 24 с.

8. Рубеж. Еженедельный литературно-художественный журнал. Орган российской эмиграции на Дальнем Востоке. Харбин, 1936. № $15.25 \mathrm{c}$.

9. Сидоров Г.М. Воспоминания скрипача. Музыкальный Харбин. Москва, 2005: Наука. С. 136-145.

10. Сун Жуй Лун. Китайсько-російсько-українські музичні зв'язки в соціокультурному континуумі Північного Китаю (на прикладі музичного життя Харбіна першої третини ХХ століття : дис. ... канд. мист. : 26.00.01 - теорія та історія культури. Львів, 2014. 199 с.

11. Успіхи українського скрипаля. Далекий Схід. Орган української еміграції на Далекому Сході. Харбін, 1938. 18 с.

12. Чорномаз В. Доля харбінського українця. Самостійна Україна. Київ, 2000. Ч. І. С. 51-55.

\section{REFERENCES}

1. Belousova V. V. (2005). My life and music. Russian Harbin. Moscow: Nauka [in Russian]. 
2. Goldstein Uriel (Julius) Moiseevich - violinist. Our Baku. History of Baku and people of Baku [in Azerbaijan].

3. The Far East (1938). Ukrainian Youth Magazine in Harbin. Harbin, August.

4. The Tenth Chamber Concert of the Harbin Symphony Society. Closing of the 1943/1944 season. Rubez. [in Cina].

5. Idzo Victor (2015). Oleksandr Dzyhar is a Ukrainian rublic figure in Harbin and Moscow. Ivano-Frankivsk: Simik [in Ukrainian].

6. Ilves M. (2000). Farewell adagio gor violin with separation. Eastern outpost. Magadan. №1 [in Russia].

7. In memory of the Russian genius (For the forthcoming production of the opera "Eugene Onegin") [1943]. Rubez, May 10 [in China].

8. Rubez [1936]. Weekly literary and art magazine. The organ of the Russian emigration in the East. Harbin, №15 [in China].

9. Sidorov G. M. (2005). Memories of a violinist. Musical Harbin. Moscow: Science. [in Russia].

10. Song Rui Long [2014). Sino-Russian-Ukrainian musical ties in the socio-cultural continuum North China. Thesis for the degree of Master of Arts in sspecialty 26.00.01. Lviv [in Ukrainian].

11. Successes of the Ukrainian violinist (1938). The Far East. The organ of Ukrainian emigration on the East. Harbin [in China].

12. Chornomaz V. (2000). The fate of the Harbin Ukrainian. Independent Ukraine. Kyiv. Ch. 1 [in Ukrainian]. 